\title{
Romancing Beale Street
}

\author{
Robert J. Corber Trinity College
}

\begin{abstract}
The author reviews Barry Jenkins's 2018 film adaptation of Baldwin's novel, If Beale Street Could Talk, finding that Jenkins's lush, painterly, and dreamlike visual style successfully translates Baldwin's cadenced prose into cinematic language. But in interpreting the novel as the "perfect fusion" of the anger of Baldwin's essays and the sensuality of his fiction, Jenkins overlooks the novel's most significant aspect, its gender politics. Baldwin began working on If Beale Street Could Talk shortly after being interviewed by Black Arts poet Nikki Giovanni for the PBS television show, Soul!. Giovanni's rejection of Baldwin's claims that for black men to overcome the injuries of white supremacy they needed to fulfill the breadwinner role prompted him to rethink his understanding of African American manhood and deeply influenced his representation of the novel's black male characters. The novel aims to disarticulate black masculinity from patriarchy. Jenkins's misunderstanding of this aspect of the novel surfaces in his treatment of the character of Frank, who in the novel serves as an example of the destructiveness of patriarchal masculinity, and in his rewriting of the novel's ending.
\end{abstract}

Keywords: If Beale Street Could Talk, Barry Jenkins, Nikki Giovanni, bearing witness, black masculinity, patriarchy, domestic violence, gender, sexuality

An avid cinephile from a young age, James Baldwin dreamed of making movies, a dream that he never managed to fulfill, despite the determination and persistence of his attempts to do so. ${ }^{1}$ In the "Autobiographical Notes" to his first published collection of essays, Notes of a Native Son (1955), he famously confessed to possessing a "morbid desire to own a sixteen-millimeter camera and make experimental films." Later in his career, he wrote several screenplays, including some based on his own novels, and he formed a production company with his former lover, Lucien Happersberger, with the goal of turning those screenplays into movies. $^{3}$ Despite his love of the cinema, however, Baldwin detested Hollywood's

James Baldwin Review, Volume 5, 2019, (c) The Authors. Published by Manchester University Press and The University of Manchester Library 
commercialism, and in The Devil Finds Work (1976), a masterpiece of film criticism that deserves more scholarly attention than it has gotten, he excoriated the film version of Billy Holiday's autobiography, Lady Sings the Blues, which he thought drained the rawness from its account of racial and sexual injustice in an attempt to render it more palatable for white audiences. Attacking the widely acclaimed film, in which Diana Ross played Holiday, he explained that "the only way to translate the written word to the cinema involves doing considerable violence to the written word, to the extent, indeed of forgetting the written word."4 The difficulties of adapting a text like Holiday's for the screen notwithstanding, Baldwin believed that the filmmaker had an obligation "to remain faithful to the intention, and the vision, of the original form," an obligation that entailed making "subtle and difficult choices." Thus, according to Baldwin, any deviation from the original author's vision should be understood as intentional on the part of the filmmaker, as it was the result of "deliberate choices, deliberately made."6

Baldwin's analysis of the work of adaptation raises the question; how would he have viewed Barry Jenkins's recent film version of his novel If Beale Street Could Talk (1974)? Narrated by its pregnant, 19-year-old female protagonist, Tish, Baldwin's novel elaborates his deeply held belief in the redemptive powers of love. ${ }^{7}$ In a series of flashbacks, Tish relates her and her family's struggle to free her lover Fonny, a 22-year-old sculptor, from prison after he has been falsely accused of raping a Puerto Rican woman. A racist beat cop, who resents Fonny's presence in Greenwich Village as an affront to his manhood, deceives the traumatized rape victim into believing that Fonny was the perpetrator, and she picks Fonny out of a police line-up in which he is the only black man. The novel emphasizes the purity and grace of Tish and Fonny's love, a purity and grace that enables them to endure the racial inequality of American society without succumbing to bitterness and despair.

The novel repeatedly describes their love for each other in religious terms. Tish and Fonny have been friends since they were children in Harlem, and when they realize they have fallen in love with each other, Tish muses, "It's a miracle to realize that somebody loves you." Later, when they make love for the first time, Fonny appears "sacred" to Tish, and the mixture of blood and ejaculate that drips down their bodies resembles "some strange anointing." ${ }^{2}$ Later still, Tish and Fonny's violent encounter with the racist cop fails to spoil their jubilation over finding a landlord who is willing to rent them a loft in Soho, even though they know the cop will never forget the encounter. The cop had attempted to arrest Fonny for beating up a white boy who sexually harassed Tish while she was shopping for groceries, but the Italian woman who owns the grocery store prevented him from doing so by corroborating Tish's account of the incident, thereby emasculating the cop in front of the crowd that had gathered around the store. Tish observes, "When two people love each other, when they really love each other, everything that happens between them has something of a sacramental air." 10

Jenkins's dedication of his adaptation of If Beale Street Could Talk to "Jimmy Baldwin," which appears at the beginning of the closing credits, suggests that he aspired to make the sort of film that Baldwin himself might have made had he 
adapted the novel, and he has largely succeeded in doing so. The director has suggested that he was drawn to If Beale Street Could Talk because of its emphasis on the importance of "sensuality and love."11 According to him, the novel represents the "perfect fusion" of Baldwin's anger over the persistence of racial injustice in the wake of the civil rights and Black Power movements and the part of his identity as a writer that was "deeply sensual, innately in touch with human emotions." ${ }^{\prime 2}$ Developed in collaboration with cinematographer James Laxton, Jenkins's trademark visual style-lush, painterly, and dreamlike-works here to translate the novel's sensuality into cinematic language. One sequence in the film especially exemplifies this achievement. In the sequence, Fonny (Stephan James) appears in medium shot pensively smoking a cigarette while working on a sculpture in the basement apartment in the Village that he shares with Tish. The camera slowly rotates around him as the smoke from his cigarette swirls above him in the opposite direction. Jenkins removed the roof of the set and flooded it with sunlight so the sequence would have a "heightened quality." ${ }^{13}$ As film critic Manohla Dargis has pointed out, the effect is to render Fonny "beautiful, holy," an effect that Nicholas Britell's anguished, mournful musical score amplifies. ${ }^{14}$ In this way, Jenkins translates into visual terms Tish's view of Fonny in the novel.

Sequences like this one have led some critics to complain that the film's visual style is too lush, too sensual, and that it airbrushes out the novel's gritty realism. For example, Doreen St. Felix, a critic for The New Yorker, avers that the film's setting, 1970s Harlem, is "deliberately idealized, manicured, and light-dappled. Even the ugliness that is included has been polished to a sheen." ${ }^{15}$ Jenkins himself seems to have worried that the film's cinematography might throw off the novel's balance between anger and sensuality that so moved him. For this reason, he at one point interrupts the film's narrative flow by cutting abruptly to a montage of black and white photographs documenting the history of racist policing in the United States, as Kiki Layne, who plays Tish, reads in voiceover a fiery passage from the novel in which Baldwin seems to have temporarily displaced Tish as its narrator:

Though the death took many forms, though people died early in many different ways, the death itself was very simple, and the cause was simple, too: as simple as a plague: the kids had been told that they weren't worth shit and everything they saw around them proved it. They struggled, they struggled, but they fell, like flies, and they congregated on the garbage heaps of their lives, like flies. ${ }^{16}$

Here Jenkins attempts to prevent the viewer from surrendering fully to the film's manifold visual pleasures. Ironically, critics' complaints about the film's gorgeousness uncannily recall the criticisms that some of Baldwin's contemporaries leveled against his prose. For example, when Baldwin's publisher Knopf sent an advance copy of Go Tell It on the Mountain (1952) to the poet Langston Hughes in the hopes that he would blurb it, he protested in a letter to Arna Bontemps that the younger writer "over-poeticizes in images way over the heads of the people supposedly thinking them" and that the novel was a "low-down story in a velvet 
bag." ${ }^{17}$ Pointing to an affinity between him and Baldwin, these criticisms suggest that Jenkins may be the Hollywood director best suited to translating the Jamesian cadences of Baldwin's prose to the cinema. ${ }^{18}$

One problem with Jenkins's emphasis on the sensuality of Tish and Fonny's love is that it calls attention to an aspect of Baldwin's work that conflicts with his recent emergence as a standard-bearer of queer culture and activism. ${ }^{19}$ In arguably the most perceptive recent book-length study of Baldwin, Douglas Field contends that the writer's sacramentalization of love reflects the continuing influence of the Black Church on his life and thought. Although Baldwin objected to institutionalized religion in all its forms, he continued to believe in the need for an authentic spiritual existence, which he thought love could best provide. ${ }^{20}$ Field's argument is persuasive, but Baldwin's insistence on love's redemptive power cannot be understood apart from his criticisms of the norms and practices that defined postwar gay life, in particular the anonymous sexual encounters in which some gay men regularly engaged. Baldwin saw sex as devoid of meaning and value, unless like the mixture of blood and ejaculate that "anoints" Tish and Fonny, it sanctified the bond between lovers.

Baldwin first expressed his aversion to gay modes of sociability in his essay "The Male Prison," originally published in 1954, in which he discussed André Gide's guilt-ridden homosexuality. There he claimed, "It does not take long . . . to discover that sex is only sex, that there are few things on earth more futile or more deadening than a meaningless round of conquests." ${ }^{21}$ Three decades later, in the wake of gay liberation, Baldwin echoed this view in his last published essay, "Freaks and the American Ideal of Manhood" (1985) by declaring that "there is nothing more boring ... than sexual activity as an end in itself, and a great many people who came out of the closet should reconsider."22 Baldwin's disapproval manifests itself in his novels in images that bear an unsettling resemblance to the homophobic discourse of the period, which painted gay life as desperate, furtive, and meaningless. For example, in Another Country (1960), when the gay actor Eric leaves his lover Yves behind in the south of France and returns to New York to begin rehearsals for a Broadway play, he deliberately avoids returning the looks of the men who cruise him as he wanders through the Village: "Strange peoplethey seemed strange to him now, but one day, again, he might be one of thempassed him with that ineffable, sidelong, desperate look; but he kept his eyes on the pavement. Not yet, not you. Not yet. Not yet." ${ }^{23}$ Later in the novel, Eric disparages the gay men who seek out the longshoremen who frequent a bar on his block: "It all seems very sad to me, but maybe I've been away too long. I don't go for back-alley cock-sucking." ${ }^{24}$

In interpreting Baldwin's novel as the "perfect fusion" of the fiery rhetoric of his essays and the sensuality of his fiction, Jenkins overlooked its most significant aspect, its gender politics. ${ }^{25}$ Baldwin began work on the novel shortly after being interviewed by Black Arts poet Nikki Giovanni for a special two-part episode of the television show Soul!, broadcast on 15 and 21 December 1971 and later published as A Dialogue. ${ }^{26}$ Baldwin's portrayal of the black male characters in the 
novel, especially Fonny and his father, Frank, indicates that his contentious exchange with Giovanni had prompted him to reconsider his understanding of black masculinity. The exchange also seems to have influenced his decision to use a first-person female narrator in the novel, something that he had never done before and would never do again. The interview quickly turned testy when Giovanni raised the topic of domestic violence: "I don't understand how a black man can be nothing in the streets and so fearful in his home, how he can be brutalized by some white person somewhere and then come home and treat me or $[\mathrm{my}][\mathrm{m}]$ other the same way that he was treated." ${ }^{27}$ Citing his stepfather's struggles to support him and his eight half brothers and sisters as evidence, Baldwin explained the violence in terms of black men's lack of access to patriarchal privilege: "You know, a black man is forbidden by definition, since he's black, to assume the roles, burdens, duties and joys of being a man." ${ }^{28} \mathrm{He}$ went on to explain, "Your manhood is being slowly destroyed hour by hour, day by day. Your woman's watching; you're watching her watch it." ${ }^{29}$ But the feminist Giovanni refused to accept this explanation, and Baldwin turned defensive and condescending. $\mathrm{He}$ repeatedly called her "sweetheart," pulled rank on her, and insisted that she needed to "understand the man's point of view." ${ }^{30}$ Finally, when Baldwin pronounced that if a man cannot provide for his family "in my own eyes I'm not a man," an exasperated Giovanni reminded him that black women could provide for themselves by declaring, "I can get my own damn steak." 31

Scholars have tended to explain Baldwin's defense of patriarchal gender arrangements in the interview and elsewhere in terms of the radicalization of the black freedom struggle in the $1960 \mathrm{~s}^{32}$ Leaders of the Black Power movement like Eldridge Cleaver regarded homosexuality as a "white man's disease," and they denounced Baldwin's gender and sexual nonconformity as incompatible with the militant black manhood that the overturning of racial inequality supposedly required. Moreover, as Black Nationalism came to dominate African American culture and politics, Baldwin's impassioned attacks on white supremacy in The Fire Next Time and other essays were suddenly read as "integrationist"; that is, as designed to appeal to white liberal guilt. In response to his waning popularity as a black public intellectual and seeking to appease Cleaver and other critics who argued that his homosexuality disqualified him from speaking for the movement, Baldwin, the argument goes, increasingly incorporated Black Nationalist rhetoric into his writings and speeches. Baldwin does seem to have accepted, if not internalized, the virulently homophobic attacks on his identity. For example, at the beginning of No Name in the Street (1972), generally considered the most militant of his writings, he wonders how the childhood friend he is visiting in Harlem views him: "What in the world was I by now but an aging, lonely, sexually dubious, politically outrageous, unspeakably erratic freak?"33 At the same time, Baldwin also sought to differentiate himself from the homophobic stereotypes in which so many black nationalists trafficked. Near the end of No Name in the Street he defends Cleaver's notorious attack on him in Soul on Ice (1968), Cleaver's memoir of prison life in which he made the outrageously homophobic claim that Baldwin 
wanted to have a white man's baby, and suggests that Cleaver had confused him with "the unutterable debasement of the male-with all those faggots, punks, and sissies, the sight and sound of whom, in prison, must have made him vomit more than once." ${ }^{34}$

But underlying Baldwin's defense of the patriarchal family was a desire to bear witness to his stepfather's pain and humiliation as a failed Baptist preacher who could barely provide for his wife and children in a society that prevented black men from fulfilling the breadwinner role fundamental to prescriptive norms of American manhood. An angry and bitter man who eventually went mad, his stepfather ruled the family with an iron hand, and Baldwin detested him. ${ }^{35}$ David Baldwin was particularly hard on the young James, whose presence in the household constantly reminded him of his wife's "immoral" relationship with James's biological father before they were married. David Baldwin also strongly disapproved of his precocious stepson's love of reading and the cinema as "the devil's work." Although Baldwin never reconciled with his stepfather, he came to understand his need to dominate the family while working at a New Jersey defense plant, where Baldwin encountered Jim Crow for the first time in his life and nearly went mad like his stepfather. In his autobiographical essay Notes of a Native Son (1955), he explains that his experience at the defense plant revealed to him "the meaning of all my [stepfather's] bitter warnings . . . the secret of his proudly pursed lips and rigid carriage: I had discovered the weight of white people in the world." 36 As a result, he begins to worry that he will suffer the same fate as his stepfather: "I saw that this had been for my ancestors and now would be for me an awful thing to live with and that the bitterness which had helped to kill my [stepfather] could also kill me." ${ }^{37}$

Frank's shame and anguish in If Beale Street Could Talk suggests that Baldwin's exchange with Giovanni had led him to rethink how he bore witness to his stepfather's struggles. Frank recalls the abusive black man whose terrorizing of his wife and children Giovanni continued to denounce, despite Baldwin's repeated attempts to "explain" it. For example, in the scene in the novel in which Tish informs Fonny's family that she is pregnant, Frank, in a shocking eruption of patriarchal violence, strikes his deeply religious wife so hard that she tumbles to the floor for glaring at Tish and prophesying that "The Holy Ghost will cause that child to shrivel in your womb." ${ }^{38}$ Echoing his deeply problematic claims about domestic violence in the interview, Baldwin attempts to explain Frank's brute demonstration of patriarchal authority in terms of his emasculation by a racist society. When he and Tish's father Joseph plot how they will raise the money for Fonny's lawyer, Frank reveals his sense of failure as a father, which has made him doubt his manhood: "I don't know if I was ever any kind of father to [Fonny] - any kind of real father-and now he's in jail and it ain't his fault and I don't even know how I'm going to get him out. I'm sure one hell of a man." ${ }^{39}$ But in contrast to the interview, Baldwin here emphasizes the destructiveness of patriarchal masculinity. Frank genuinely loves his daughters but he cannot express that love because of his shame over his failure to fulfill society's expectations of men, and instead he constantly abuses them verbally. In the novel's final pages, Joseph witnesses this 
abuse and suddenly realizes that Frank's daughter Adrienne "loves her father with a really desperate love. She knows he is in pain. She would soothe it if she could, she does not know how. She would give anything to know how." 40 Thus Frank's violent assertion of his manhood prevents him from experiencing the redemptive powers of love, and he eventually takes his own life.

Frank belongs to a long line of self-destructive black male characters in Baldwin's fiction, starting with the embittered narrator of his first published work of fiction, the short story "Previous Condition" (1948). But If Beale Street Could Talk differs significantly from Baldwin's earlier fiction in providing a counter-example of African American fatherhood in its portrayal of Joseph. ${ }^{41}$ Although Joseph too has struggled to provide for his family, unlike Frank he never experiences that struggle as emasculating. Thus he has no need to compensate for his lack of power as a black man by aggressively asserting his masculinity. Joseph does not understand Frank's desolation, and Joseph dismisses his concerns about their ability to raise the money to pay for Fonny's lawyer:

If we start worrying about money now man, we going to be fucked and we going to lose our children. That white man, baby ... he want you to be worried about the money. That's his whole game. But if we got to where we are without money, we can get further. ${ }^{42}$

Moreover, because he lacks Frank's paralyzing sense of shame, he has no difficulty expressing his love for his daughters. Indeed, his relationship with them exemplifies Baldwin's understanding of the "miracle" of love. When Tish reaches a low point in her pregnancy, he tells her to quit her job selling perfume at a department store and promises that he will make up for the family's loss of income:

We got to take care of each other in this world, right? Now: there are some things I can do that you can't do. That's all. There's things I can do that you can't do-and things you can do that $I$ can't do, just like I can't have your baby for you. I would if I could. ${ }^{43}$

Baldwin's portrayal of Fonny provides more evidence that his exchange with Giovanni influenced his exploration of black manhood in the novel. Like Joseph, Fonny reflects Baldwin's desire to provide readers with an example of black masculinity that is disentangled from patriarchy. Fonny never attempts to assert power over Tish. Although when she places herself between him and the racist cop who threatens to arrest him he becomes angry and warns her, "Don't ever try to protect me again," he later apologizes, conceding that she did "nothing wrong. I guess you did the only thing you could have done. But you got to understand where I'm coming from." ${ }^{44}$ Moreover, in sharp contrast to his father, Fonny never questions his own masculinity. He has avoided the fate of the other neighborhood boys, who end up robbing stores and on drugs, because unlike them he "had found his center, his own center, inside him: and it showed." ${ }^{45}$ For this reason, his presence in the Village threatens the cops who expect black men to fear them. Tish remarks, 
"You're supposed to be somebody's nigger. And if you're nobody's nigger, you're a bad nigger: and that's what the cops decided when Fonny moved downtown."46 Nor does he ever succumb to despair, even when Tish informs him that his trial has been indefinitely postponed because his accuser has disappeared in Puerto Rico. Although during one of her visits to the prison, Fonny reveals that he has discovered, "I'm not as tough as I thought I was. I'm younger than I thought I was," Tish nevertheless leaves convinced that the two of them "are going to make it, somehow." ${ }^{37}$ When her mother later asks how Fonny is holding up, she replies, "He's beautiful. They beat him up, but they didn't beat him-if you see what I mean. He's beautiful." 48

That Jenkins does not fully grasp the significance of Baldwin's exploration of black masculinity becomes clear in his representation of Frank (Michael Beach). Although he includes the scene at the bar when a despondent Frank betrays his sense of failure as a man, he omits from the film Joseph's discovery of how much Adrienne loves her father, despite his abusive treatment of her, as well as Frank's suicide. ${ }^{49}$ Thus viewers unfamiliar with the novel do not know that Frank serves as an example of the destructiveness of patriarchal masculinity. The consequences of this for the film become apparent in the scene in which Frank knocks his wife to the floor when she curses Tish's unborn baby. Jenkins has adapted the scene almost verbatim from the novel, except it should be noted that he omits Tish's sister Ernestine's homophobic description of the Holy Ghost as a "faggot." ${ }^{50}$ How should viewers react to the sudden intrusion of domestic violence into the film? Should they think that the sanctimonious Mrs. Hill deserves to be slapped? Or should they dismiss the violence as an artifact of an earlier period when the domestic abuse of women was supposedly more common? Jenkins realizes that the scene may confuse as well as unsettle viewers. In an interview for the Atlantic, he points out somewhat defensively that when Frank strikes his wife, Joseph (Coleman Domingo) exhorts him in voice-off, "Don't hit your woman," and that Sharon (Regina King) forces Frank and her husband from the apartment and immediately bolts the door so they cannot re-enter. Implying that Sharon has solved the problem of Frank's abusive behavior, Jenkins explains, "The men are out there; the women are in here." ${ }^{51}$ But this treatment of Frank's violent assertion of patriarchal power fails to convey Baldwin's expectation that readers of the novel would object to it even as they understood the rage and despair underlying it. Consequently, Frank's role in the film remains unclear.

The film's ending, which differs significantly from that of the novel, further indicates Jenkins's misunderstanding of the novel's gender politics. As Joyce Carol Oates observed in her review of the novel shortly after its publication, Baldwin's ending conveys limited optimism about Tish and Fonny's future: "Fonny is out on bail, his trial postponed indefinitely, neither free nor imprisoned but at least returned to the world of the living." 52 In contrast, Jenkins's adaptation ends with a kind of coda in which several years after the main action Tish visits Fonny in prison with their toddler son who, having learned from Tish when his father will be released, has begun to write the prison release date everywhere. In ending this 
way, the film shifts the focus from the importance of romantic and familial bonds forged in struggle to another topic, the mass incarceration of black men, that Baldwin certainly cared deeply about and that figures prominently in the novel. Indeed, while he was working on the novel Baldwin was simultaneously waging a campaign for the release of Tony Maynard, his "man Friday," who was awaiting trial on a murder charge..$^{53}$ But while Baldwin's ending alludes to the issue of mass incarceration-Fonny continues to face the possibility of false imprisonment-it focuses attention primarily on the differences between Fonny and his father. The novel's final image is of Fonny working on a sculpture in his studio, "whistling, smiling," with his and Tish's baby nearby crying. Such an image emphasizes Fonny's resilience as a man who has found his "center," thanks in part to the love of Tish and her family, and who has no need to prove his masculinity. ${ }^{54}$

Despite Baldwin's assertions to the contrary in The Devil Finds Work, Jenkins's only obligation in adapting If Beale Street Could Talk was of course to remain faithful to his own vision as a filmmaker. Moreover, it seems likely that Baldwin would have welcomed the director's revision of the ending, given that it provided viewers with a powerful reminder of the lack of progress in the black freedom struggle since the 1970s. As Baldwin famously declared in "Black English: A Dishonest Argument," a speech that he gave at Wayne State University in 1980, "I want to suggest that history is not the past. It is the present. We carry our history with us. We are our history. If we pretend otherwise, to put it very brutally, we literally are criminals." ${ }^{35}$ Jenkins's ending, in which Fonny is serving a prison sentence for a rape that he did not commit, shows that he has heeded Baldwin's warning. Such an ending prevents viewers from dismissing the film's portrayal of racist policing as a relic of the past by alluding to its continuation into the present. Nevertheless, Jenkins's failure to address Baldwin's goal of disarticulating black masculinity from patriarchal power represents a significant omission on the part of the Academy Award winning director of Moonlight (2016). A visually stunning adaptation of an unpublished autobiographical play by Tarell McCraney, Moonlight explored the role of race in the construction of gender and sexual identities by tracing the coming of age of Chiron, a young gay black man who endures physical and verbal abuse while struggling to come to terms with his homosexuality. Thus in disregarding Baldwin's aim to provide readers with an alternative model of African American manhood, Jenkins missed an opportunity to continue his exploration of the complicated nexus of race, gender, and sexuality in American society that he began in Moonlight.

\section{Notes}

1 For a discussion of how Baldwin's love of the cinema shaped his queer identity, see Robert J. Corber, "Queering I Am Not Your Negro: Or Why We Need James Baldwin More Than Ever," James Baldwin Review, 3 (2017), pp. 163-6. For an important discussion of the influence of the cinema on Baldwin's work, see David Gerstner, Queer Pollen: White Seduction, Black Male Homosexuality, and the Cinematic (Champaign, IL, University of Illinois Press, 2011), pp. 73-137. 
2 James Baldwin, Notes of a Native Son (Boston, MA, Beacon Press, 2012), p. 8.

3 See David Leeming, James Baldwin: A Life (New York, Arcade Publishing, 1994), pp. 243-4.

4 James Baldwin, The Devil Finds Work (New York, Vintage, 2011), pp. 111-12.

5 Ibid., p. 112.

6 Ibid.

7 Baldwin provided a concise explanation of his conception of love in The Fire Next Time. There he noted, "I use the word 'love' ... not merely in the personal sense but as a state of being, or a state of grace-not in the infantile American sense of being made happy but in the tough and universal sense of quest and daring and growth." James Baldwin, The Fire Next Time (New York, Vintage, 1993), p. 95. In many respects, Tish and Fonny's love illustrates this conception.

8 James Baldwin, If Beale Street Could Talk (New York, Vintage, 2006), p. 42.

9 Ibid., pp. 79, 81.

10 Ibid., p. 143.

11 David Sims, "How Barry Jenkins Turned His James Baldwin Obsession Into His Next Movie," The Atlantic, December 2018, www.theatlantic.com/entertainment/archive/2018/12/ barry-jenkins-if-beale-street-could-talk-interview/577528 (accessed 3 February 2019).

$12 \mathrm{Ibid}$.

13 Ibid.

14 Manohla Dargis, "Trusting Love in a World Ruled by Hate," New York Times, 12 December 2018, www.nytimes.com/2018/12/12/movies/if-beale-street-could-talk-review. html (accessed 17 February 2019).

15 Doreen St. Felix, "Can We Trust the Beauty of Barry Jenkins's 'If Beale Street Could Talk?" New Yorker, 21 December 2018, www.newyorker.com/culture/cultural-comment/ can-we-trust-the-beauty-of-barry-jenkinss-if-beale-street-could-talk (accessed 3 February 2019).

16 Baldwin, If Beale Street Could Talk, p. 36.

17 Quoted in James Campbell, Talking at the Gates: A Life of James Baldwin (Berkeley, CA, University of California Press, 2002), p. 94.

18 In the 1960s when the masculinism of the Black Power movement dominated African American politics and culture, criticizing Baldwin's cadenced prose enabled a younger generation of African American writers to attack him indirectly for his homosexuality, which they saw as incompatible with a militant black manhood. For a discussion of these attacks, see Douglas Field, All Those Strangers: The Art and Lives of James Baldwin (Oxford, Oxford University Press, 2015), pp. 66-81. See also Robert J. Corber, Homosexuality in Cold War America: Resistance and the Crisis of Masculinity (Durham, NC, Duke University Press, 1997), pp. 160-90.

19 For a good discussion of this emergence, see Matt Brim, James Baldwin and the Queer Imagination (Ann Arbor, MI, University of Michigan Press, 2014), pp. 23-54.

20 Field, All Those Strangers, pp. 82-112.

21 James Baldwin, “The Male Prison," in Collected Essays, ed. Toni Morrison (New York, Library of America, 1998), p. 234.

22 James Baldwin, "Freaks and the American Ideal of Manhood," in Morrison (ed.), Collected Essays, p. 827.

23 James Baldwin, Another Country (New York, Vintage, 1993), p. 267; emphasis in original.

24 Ibid., p. 333, emphasis in original. 
25 Sims, "How Barry Jenkins Turned His James Baldwin Obsession Into His Next Movie."

26 For a detailed history of this remarkable television series broadcast on PBS stations between 1968 and 1973, see Gayle Wald, It's Been Beautiful: Soul! and Black Power Television (Durham, NC, Duke University Press, 2015). See also Devorah Heitner, Black Power TV (Durham, NC, Duke University Press, 2008), pp. 123-52.

27 James Baldwin and Nikki Giovanni, A Dialogue (New York, Lippincott, 1973), p. 43. It is important to note that $A$ Dialogue does not include all of the interview.

28 Ibid., p. 40.

29 Ibid., p. 42.

30 Ibid., p. 50.

31 Ibid., p. 55.

32 See, for example, Field, All Those Strangers, pp. 66-81. I have made similar claims. See especially Corber, "Queering I Am Not Your Negro," pp. 166-7. My argument in the present essay represents my reassessment of Baldwin's masculinist rhetoric.

33 James Baldwin, No Name in the Street (New York, Vintage, 2007), p. 18.

34 Ibid., pp. 172-3.

35 In his writings and public appearances Baldwin always referred to David Baldwin as his father to show, I think, respect to the man who provided for him, however inadequately, when he was a child.

36 Baldwin, Notes of a Native Son, p. 90.

37 Ibid.

38 Baldwin, If Beale Street Could Talk, p. 68.

39 Ibid., p. 126, emphasis in original.

40 Ibid., p. 190.

41 The biblical Joseph's status as a model father may explain Baldwin's choice of name for Tish's father.

42 Baldwin, If Beale Street Could Talk, p. 125, emphasis in original.

43 Ibid., p. 160, emphasis in original.

44 Ibid., pp. 140, 141.

45 Ibid., p. 37.

46 Ibid., pp. 37-8, emphasis in original.

47 Ibid., pp. 183, 184.

48 Ibid., p. 196.

49 Jenkins apparently filmed a version of the ending that revealed Frank's suicide, but he did not think it "worked" and cut it from the final version of the film. See St. Felix, "Can We Trust the Beauty of Barry Jenkins's 'If Beale Street Could Talk'?"

50 Baldwin, If Beale Street Could Talk, p. 74. The characters in the novel regularly use such homophobic language, which provides more evidence of Baldwin's desire to distinguish his gender and sexual nonconformity from that of the "faggot." Jenkins's omission of this language from his adaptation exemplifies a troubling tendency in both scholarship and popular culture to gloss over or suppress problematic or unsettling aspects of Baldwin's work. For a discussion of this tendency, see Field, All Those Strangers, pp. 8-10.

51 Sims, "How Barry Jenkins Turned his James Baldwin Obsession into his Next Movie."

52 Joyce Carol Oates, "If Beale Street Could Talk," New York Times, 19 May 1974, http://movies2.nytimes.com/books/98/03/29/specials/baldwin-beale.html (accessed 21 February 2019). 
53 Baldwin describes in detail his struggle to free Maynard in No Name in the Street, pp. 100-17.

54 Baldwin, If Beale Street Could Talk, p. 197

55 James Baldwin, "Black English: A Dishonest Dialogue," in The Cross of Redemption: Uncollected Writings, ed. Randall Kenan (New York, Vintage, 2011), p. 154, emphasis in original.

\section{Works Cited}

Baldwin, James, Another Country (New York, Vintage, 1993).

"Black English: A Dishonest Dialogue," in The Cross of Redemption: Uncollected

Writings, ed. Randall Kenan (New York, Vintage, 2011), pp. 154-60.

Collected Essays, ed. Toni Morrison (New York, Library of America, 1998).

The Cross of Redemption: Uncollected Writings, ed. Randall Kenan (New York,

Vintage, 2011).

The Devil Finds Work (New York, Vintage, 2011).

The Fire Next Time (New York, Vintage, 1993).

"Freaks and the American Ideal of Manhood," in Collected Essays, ed. Toni Mor-

rison (New York, Library of America, 1998), pp. 814-29.

If Beale Street Could Talk (New York, Vintage, 2006).

"The Male Prison," in Collected Essays, ed. Toni Morrison (New York, Library of

America, 1998), pp. 231-5.

No Name in the Street (New York, Vintage, 2007).

Notes of a Native Son (Boston, MA, Beacon, 2012).

and Nikki Giovanni, A Dialogue (New York, Lippincott, 1973).

Brim, Matt, James Baldwin and the Queer Imagination (Ann Arbor, MI, University of Michigan Press, 2014).

Campbell, James, Talking at the Gates: A Life of James Baldwin (Berkeley, CA, University of California Press, 2002).

Corber, Robert J., Homosexuality in Cold War America: Resistance and the Crisis of Masculinity (Durham, NC, Duke University Press, 1997).

"Queering I Am Not Your Negro: Or Why We Need James Baldwin More Than Ever," James Baldwin Review, 3 (2017), pp. 161-72.

Dargis, Manohla, “Trusting Love in a World Ruled by Hate," New York Times, 12 December 2018, www.nytimes.com/2018/12/12/movies/if-beale-street-could-talk-review.html (accessed 17 February 2019).

Field, Douglas, All Those Strangers: The Art and Lives of James Baldwin (Oxford, Oxford University Press, 2015).

Gerster, David, Queer Pollen: White Seduction, Black Male Homosexuality, and the Cinematic (Champaign, IL, University of Illinois Press, 2011).

Heitner, Devorah, Black Power TV (Durham, NC, Duke University Press, 2013).

Leeming, David, James Baldwin: A Biography (New York, Arcade Publishing, 1994).

Oates, Joyce Carol, "If Beale Street Could Talk," New York Times, 19 May 1974, http://movies2.nytimes.com/books/98/03/29/specials/baldwin-beale.html (accessed 21 February 2019).

St. Felix, Doreen, “Can We Trust The Beauty of Barry Jenkins's 'If Beale Street Could Talk'?, New Yorker, 21 December 2018, www.newyorker.com/culture/cultural-comment/can-wetrust-the-beauty-of-barry-jenkinss-if-beale-street-could-talk (accessed 3 February 2019). 
Sims, David, "How Barry Jenkins Turned His James Baldwin Obsession Into His Next Movie," The Atlantic, December 2018, www.theatlantic.com/entertainment/archive/ 2018/12/barry-jenkins-if-beale-street-could-talk-interview/577528 (accessed 3 February 2019).

Wald, Gayle, It's Been Beautiful: Soul! and Black Power Television (Durham, NC, Duke University Press, 2015).

\section{Contributor's Biography}

Robert J. Corber is William R. Kenan, Jr. Professor in American Institutions and Values at Trinity College (CT). He is the author and editor of several books, including most recently a scholarly edition of the 1932 queer novel, A Scarlet Pansy. He is currently writing a book on Baldwin, tentatively entitled A Prodigious Rage: Militancy, Masculinity and Queer Identity in James Baldwin. 